\title{
PEMBELAJARAN DENGAN METODE DWIBAHASA ANTARA BAHASA IBU DENGAN BAHASA INDONESIA DAN BAHASA INDONESIA DENGAN BAHASA INGGRIS
}

\author{
Yuliana Susanti \\ Universitas Terbuka \\ Email : annasusanto18@gmail.com
}

\begin{abstract}
This research was conducted based on the development of education in West Java where the development of international standard schools as an implication of globalization. The curriculum developed in these schools is more concerned with aspects of mastering a foreign language (English) in every educational process. The purpose of this study was (1) to see the dangers found in the process of acquiring a second language (Indonesian) and a third language (English) through elementary school science learning in classes using Sundanese and Indonesian as the language of instruction with classes using the language. Indonesian and English; and (2) to see the emergence of the mother tongue in the science learning process. The research subjects were elementary school students in Bandung Regency, namely in the Solokan Jeruk District and the UPI Laboratory SD Cibiru Campus. Observation data observation techniques on the learning process whose results are described qualitatively. The method of observation is carried out on situations that occur in class. The results showed that students in Solokan Jeruk District still dominantly use Sundanese in the learning process. The teacher tries to adjust the language of instruction to the students' abilities. The teacher also tries to guide students in understanding the subject matter using Indonesian. The results of research at the UPI Laboratory Elementary School Cibiru Campus show that the English language skills of the UPI Laboratory Elementary School students in Cibiru Campus are quite good. Students get to know various English vocabularies about things related to nature. However, the learning process does not seem to apply Sundanese as the language of instruction at all. The suggestion put forward is that the science learning process should not override the preservation of Sundanese language. Sundanese language can be applied to integrated science learning in tribal languages along with Indonesian and English. It is also hoped that this can improve students' language skills in a more comprehensive manner which is adjusted to the level of student language development
\end{abstract}

\section{PENDAHULUAN}

Pembelajaran Sains dengan media instruksi bahasa Inggris telah banyak dilakukan pada siswa-siswa yang bukan penutur asli bahasa Inggris di berbagai negara, seperti di Singapura, Cina, Malaysia, dan bahkan di Indonesia pada sekolah-sekolah yang bertaraf internasional. Penggunaan bahasa Inggris dapat dilakukan dengan metode dwibahasa ataupun secara mandiri.

Globalisasi seolah-olah menjadi bagian wajib dalam mengaktualisasi ruang pendidikan dengan tuntutan untuk menjadikan bahasa Inggris sebagai pengantar dalam proses pendidikan. Lalu apakah bahasa Indonesia tidak lagi menjadi bahasa nasional kita, atau bahasa kedua setelah bahasa ibu (bahasa daerah)? Pemerintah Daerah Jawa Barat semakin mengedepankan kemunculan sekolah-sekolah berstandar internasional sebagai implikasi dari globalisasi. Kita sering menjumpai buku-buku teks yang dipakai di sekolah-sekolah ditulis dalam bahasa Inggris, biasanya digunakan sebagai buku sumber utama dalam mata pelajaran tertentu. Hal ini terutama terjadi di sekolah-sekolah Indonesia yang berstandar internasional sebagai implikasi dari aplikasi kurikulum bertaraf global.

Munculnya model baru di bidang pendidikan dasar ini menyebabkan pembelajaran di sekolah dasar yang mengajarkan materi subjek dalam bahasa Inggris sebagai media instruksi. Sekolah dasar di berbagai Negara, seperti Singapura, Cina, Malaysia, dan bahkan di Indonesia sekali pun telah mengaplikasikan bahasa Inggris sebagai media instruksi dalam mata pelajaran 
Matematika dan Sains secara dwibahasa atau menggunakan bahasa Inggris $100 \%$. Pemerintah Daerah Jawa Barat semakin mengedepankan kemunculan sekolah-sekolah berstandar internasional sebagai implikasi dari globalisasi. Konsekuensi dari hal tersebut adalah bahwa siswa pun ditekankan untuk harus memiliki keterampilan bahasa Inggris untuk dapat menguasai berbagai materi subjek. Kepanikan ini ikut dirasakan oleh para orang tua yang beramai-ramai mengirim putra-putrinya mengikuti kursus bahasa Inggris di berbagai lembaga. Di sisi lain, sekolah menentukan kebijakan bahwa guru harus memiliki keterampilan bahasa Inggris yang baik agar mampu mengajarkan materi subjek menggunakan bahasa pengantar bahasa Inggris (Margaretha, et.al., 2008). Hal ini terus mendorong timbulnya kesenjangan yang besar antara kepentingan menguasai bahasa Inggris, bahasa Indonesia, dan bahasa ibu (Sunda). Akibatnya, bahasa nasional apalagi bahasa ibu semakin dikesampingkan kepentingan dan penggunaanya. Kemerosotan nilai prestise bahasa Sunda dirasakan semakin kuat di kalangan pendidik dan siswa didik yang mengajar dan belajar di sekolah-sekolah tersebut.

Lain halnya dengan sekolah di daerah pedesaan. Jangankan belajar menggunakan bahasa Inggris sebagai bahasa pengantar, membaca buku teks bahasa Inggris, atau berkomunikasi dalam bahasa Inggris, kemampuan berbahasa Indonesia pun masih rendah (Heryadi, Sulfemi, \& Retnowati, 2020). Umumnya siswa pada sekolah tersebut masih menggunakan bahasa Sunda sebagai bahasa pengantar, termasuk dalam mata pelajaran Sains. Walaupun guru sudah merancang pembelajaran dalam bahasa Indonesia, tetap saja dalam pelaksanaannya siswa seringkali menggunakan bahasa Sunda dalam penyampaian pendapat.

Kesenjangan seperti ini makin dapat dirasakan di era globalisasi. Namun, hal ini justru memberikan peluang positif bagi daerah untuk dapat mempertahankan kelestarian bahasa Sunda sebagai identitas budaya lokal. Berdasarkan latar belakang tersebut, tujuan penelitian kali ini adalah untuk: (1) mengetahui kendala yang dihadapi siswa dalam pemerolehan bahasa ke dua (bahasa Indonesia) dan bahasa ke tiga (bahasa Inggris) melalui proses pembelajaran Sains pada kelas yang menggunakan bahasa pengantar bahasa Sunda dan bahasa Indonesia dan pada kelas yang menggunakan pengantar bahasa Indonesia dan bahasa Inggris; dan (2) mengetahui seberapa besar kemunculan penggunaan bahasa ibu dalam proses pembelajaran.

\section{KERANGKA TEORI}

Pembelajaran terpadu diyakini dapat meningkatkan pemahaman siswa tentang kedalaman dan keluasan berbagai materi pelajaran yang diintegrasikan (Fogarty: 199: Sulfemi, \& Minati, 2018). Pengajaran Sains dan bahasa secara terpadu dapat membantu memperdalam pemahaman siswa terhadap materi Sains selain itu juga dapat meningkatkan kemampuan berbahasa siswa. Pendapat ini sejalan dengan apa yang dikemukakan oleh Haliwell (1992) dalam bukunya yang berjudul Teaching English in the Primary Classroom bahwa pengajaran materi subjek dengan media instruksi bahasa Inggris merupakan cara terbaik yang dapat dilakukan untuk menanamkan pemahaman penguasaan bahasa Inggris secara mendalam pada siswa SD. Pengajaran bahasa Inggris sebagai bahasa kedua yang diintegrasikan dengan mata pelajaran Sains disebut dengan pengajaran content based english teaching. Pengajaran dapat dilakukan secara dwibahasa atau menggunakan bahasa Inggris secara keseluruhan. (Cameron: 2001).

Dalam pembelajaran dwibahasa, guru harus mampu mengorganisasikan pembelajaran yang memungkinkan siswa bekerja secara kolaboratif sehingga tercipta interaksi antarsiswa. Guru tidak boleh memaksakan siswa untuk menggunakan bahasa Inggris atau bahasa Indonesia, tetapi harus memberikan kesempatan pada siswa untuk menggunakan bahasa pertamanya yang dalam hal ini bahasa ibu di Kabupaten Bandung adalah bahasa Sunda (Dedezade: 2006). 
Bahasa adalah sebuah produk budaya yang lahir sebagai akibat dari interaksi antarmanusia sehingga tidak dapat dilepaskan dari konteks sosial. Bahasa sebagai aktualisasi perilaku sosial yang kompleks dan terkait dengan sejarah dan proses perkembangan masyarakat setempat. Bahasa dapat tumbuh dalam bentuk verbal maupun simbolik. Dengan kata lain, bahasa tidak hanya untuk dimengerti, tetapi juga sebuah entitas atau tanda kekayaan (sign of wealth) dan tanda kekuasaan (sign of authority) yang dapat digunakan untuk memaksakan sebuah dominasi (Sulfemi, Siswanto, Heryadi, \& Soleh, 2020). Pada kenyataan sehari-hari, bahasa bukan hanya dipakai sebagai alat komunikasi, tetapi dipakai sebagai politik kepentingan antara penyampaian informasi dengan keinginan untuk mendapatkan keuntungan simbolik. Bahasa seringkali ditentukan oleh relasi kepentingan yang terjadi pada situasi tertentu. Nilai tersebut tergantung pada relasi kekuasaan yang ditentukan oleh kompetensi linguistik para pembicara dan bergantung pada kapasitas pemakai bahasa di dalamnya untuk memaksakan penerimaan dan paling menguntungkan bagi kepentingan. Kapasitas ini bukan semata-mata kapasitas linguistik, melainkan ditentukan juga oleh keseluruhan struktur sosial, berarti juga kedudukan sosial yang menyampaikan, dan tempat bahasa itu berlaku. Seperti halnya praktik penggunaan bahasa formal dalam acara-acara pertemuan antarnegara. Bahasa formal melakukan pemaksaan kepada pendengarnya yang belum tentu mengerti bahasa formal tinggi penuh jargon dan istilah asing. Bahasa formal ini memiliki kekuatan memaksa karena berkenaan dengan struktur yang berlaku. Hal ini terjadi karena memiliki legitimasi (Boudieu: 2008).

Penguasaan sebuah bahasa oleh seorang anak dimulai dengan perolehan bahasa pertama yaitu bahasa ibu. Pemerolehan bahasa merupakan sebuah proses yang sangat panjang sejak anak belum mengenal sebuah bahasa sampai fasih berbahasa. Setelah bahasa ibu diperoleh pada usia tertentu, anak mulai mempelajari bahasa kedua yang ia kenal sebagai khazanah pengetahuan yang baru. Ali (1995:77) mengatakan bahasa ibu adalah bahasa pertama yang dikuasai manusia sejak awal hidupnya melalui interaksi dengan sesama anggota masyarakat, seperti keluarga dan masyarakat sekitarnya. Hal ini menunjukkan bahasa pertama merupakan proses awal yang diperoleh anak dalam mengenal bunyi dan lambang bahasa.

\section{METODOLOGI PENELITIAN}

Metodologi penelitian yang dipilih adalah kualititatif deskriptif yang difokuskan pada teknik observasi situasi dan kondisi riil dan alami di kelas. Penelitian ini secara kolaboratif mempelajari proses pembelajaran Sains SD di kelas yang menggunakan bahasa pengantar bahasa Sunda dan bahasa Indonesia serta kelas yang menggunakan bahasa pengantar bahasa Indonesia dan bahasa Inggris. Penelitian ini melibatkan guru dan siswa SD di Kecamatan Solokan Jeruk dan di SD Laboratorium UPI Kampus Cibiru dalam interaksi selama pembelajaran berlangsung.

\section{Subjek dan Objek Penelitian}

Subjek dalam penelitian ini adalah siswa SD di Kecamatan Solokan Jeruk dan SD Laboratorium UPI Kampus Cibiru. Siswa SD di Kecamatan Solokan Jeruk memiliki latar belakang yang relatif sama jika dilihat dari tingkat kemampuan bahasa Indonesia dan bahasa Inggrisnya. Siswa dominan menggunakan bahasa ibu dalam pergaulan sehari-hari maupun dalam kelas saat pembelajaran Sains berlangsung. Namun, siswa SD Laboratorium UPI Kampus Cibiru memiliki karakteristik yang berbeda dari siswa di Kecamatan Solokan Jeruk. Siswa SD Laboratorium UPI Kampus Cibiru umumnya sudah mampu berbahasa Inggris dengan cukup

baik, tetapi jarang sekali dari mereka yang mampu berbahasa ibu. Bahasa yang sering digunakan 
adalah bahasa Indonesia dalam keseharian siswa. Adapun objek dari penelitian ini adalah kendala yang ditemui selama pembelajaran Sains berlangsung pada aspek pemerolehan bahasa ke dua (bahasa Indonesia) dan bahasa ke tiga (bahasa Inggris) pada kelas yang menggunakan bahasa pengantar bahasa ibu dan pemerolehan bahasa Indonesia pada kelas yang menggunakan pengantar bahasa Indonesia dan bahasa Inggris.

\section{Prosedur Penelitian}

Prosedur penelitian yang dilakukan meliputi tahapan-tahapan: (1) perencanaan pengajaran (diskusi rencana penelitian antara tim peneliti dengan guru SD, merancang silabus, membuat RPP, menyusun jadwal, dan menyiapkan bahan ajar); (2) pelaksanaan (implementasi pembelajaran dwibahasa pada kelas yang menggunakan bahasa pengantar bahasa Sunda dan bahasa Indonesia (SD Kecamatan Solokan Jeruk), serta di kelas yang menggunakan bahasa Indonesia dan bahasa Inggris (SD Laboratorium UPI Kampus Cibiru); dan (3) analisis data penelitian.

\section{Instrumen Penelitian}

Instrumen yang dikembangkan dalam penelitian ini adalah (1) lembar observasi keterlaksanaan pembelajaran dwibahasa, (2) catatan lapangan berupa anekdot yang merekam kejadian-kejadian yang dianggap perlu dan kritis untuk didiskusikan selama pembelajaran berlangsung, (3) lembar panduan wawancara dengan guru setelah pembelajaran berakhir, (4) dokumentasi foto pembelajaran (Sulfemi \& Mayasari, 2019).

\section{HASIL PENELITIAN DAN PEMBAHASAN \\ Pembelajaran di SD di Kecamatan Solokan Jeruk}

Pembelajaran Sains yang terjadi di SD di Kecamatan Solokan Jeruk lebih banyak menggunakan bahasa Sunda sebagai bahasa pengantar. Walaupun guru memberi pertanyaan dalam bahasa Indonesia, siswa masih menjawab dalam bahasa Sunda. Bahkan untuk dapat memahami pertanyaan guru, kadangkala guru harus menerjemahkan pertanyaan dari bahasa Indonesia ke dalam bahasa Sunda. Salah satu petikan dialog yang terjadi pada pembelajaran konsep energi adalah sebagai berikut: "Apa yang menyebabkan televisi bisa menyala?" Siswa hening tak ada yang menjawab. Setelah pertanyaan diulang dan diterjemahkan ke dalam bahasa Sunda, siswa ada yang menjawab, "TVna hurung dicolokkeun kanu listrik" (TV-nya menyala karena dihubungkan sengan sumber arus listrik).

Pemerolehan bahasa pertama anak di daerah Kecamatan Solokan Jeruk adalah bahasa Sunda karena bahasa itulah yang diperolehnya pertama kali dari lingkungan keluarga maupun pergaulan dengan teman sebaya Sulfemi, \& Yasita, (2020). Perolehan bahasa pertama terjadi apabila seorang anak yang semula tanpa bahasa kini ia memperoleh bahasa (Tarigan dalam Safarina dan Indrawati, 2006:157). Bahasa Sunda yang digunakan setiap saat sering kali terbawa ke situasi formal atau resmi yang seharusnya menggunakan bahasa Indonesia yang baik dan benar. Tidak dapat dipungkiri bahwa dialek bahasa Sunda sangat memengaruhi proses pemerolehan bahasa kedua terutama dalam hal pelafalannya. Chaer (1994) menyebutkan bahwa dialek atau pelafalan bahasa daerah dan ragam bahasa dalam tatanannya sebagai bahasa lisan memiliki dampak terhadap pelafalan bahasa Indonesia yang baik dan benar meskipun dari segi makna masih dapat diterima. Hal ini juga dapat didengar dalam pembelajaran di kelas. Namun, dialek tersebut hendaknya sekecil mungkin dihilangkan sehingga tidak menimbulkan 
permasalahan khususnya salah penafsiran bahasa oleh audiens siswa karena terdapat bahasa daerah yang mempunyai ucapan atau pelafalan sama namun memiliki makna yang berbeda (Sulfemi, 2020). Temuan hasil observasi menunjukkan bahwa kemampuan bahasa Indonesia siswa (bahasa kedua) masih rendah dan harus terus dilatih oleh guru melalui strategi pembelajaran terpadu. Namun, berdasarkan hasil wawancara dengan guru, mereka umumnya menemui kesulitan dalam mendesain pembelajaran yang memuat proses transisi berbahasa.

Dalam Whole Language for Second Language Learners, Freeman et.al. (1992) menyebutkan bahwa signifikansi penggunaan bahasa ibu sebagai bahasa pengantar di sekolah sebelum bahasa kedua dikuasai anak akan mampu menghasilkan prestasi yang lebih baik bagi anak-anak di masa mendatang. Harus ditemukan cara yang secara pedagogis mampu membuat anak nyaman ketika mengalami peralihan dari bahasa ibu mereka ke bahasa Indonesia sebagai bahasa pengantar di sekolah. Jika masalah ini dijalankan dengan baik maka kekhawatiran tentang dampak buruk pengenalan berbahasa Indonesia yang terlalu dini di sekolah tak akan terjadi. Kita patut menjaga kelestarian bahasa ibu anak-anak serta menyiapkan proses transisi berbahasa mereka agar penguasaan Bahasa Indonesia dan bahasa lainnya menjadi kuat.

Hal yang relevan dengan pendapat Freeman di atas juga disampaikan oleh beberapa Pusat Penelitian Bahasa dan Kebudayaan di beberapa Universitas bahwa bahasa pengantar di sekolah memiliki pengaruh serius terhadap keberhasilan prestasi siswa di masa depan. Murid-murid Sekolah Dasar (SD) di perkotaan umumnya adalah penutur-penutur asli bahasa Indonesia, dengan kata lain menggunakan bahasa Indonesia sebagai bahasa pertama, sedangkan murid pedesaan bahasa pertama mereka bukan bahasa Indonesia, melainkan bahasa daerahnya masingmasing. Rata-rata setiap hari mereka berjuang mempelajari bahasa Indonesia dan pada saat yang sama mereka juga harus mempelajari materi pelajaran lainnya yang juga berbahasa Indonesia. Bagi seluruh anak SD di pedesaan, ini bukanlah persoalan mudah.

\section{Pembelajaran di SD Laboratorium UPI Kampus Cibiru.}

Keterpaduan pembelajaran menggunakan bahasa pengantar bahasa Indonesia dan bahasa Inggris sudah terlihat di kelas. Siswa antusias belajar mengenai bagian-bagian tubuh hewan dalam bahasa Inggris. Bila dilihat dari data observasi, penggunaan bahasa Inggris sebagai bahasa pengantar lebih dari 50\%. Akan tetapi, dalam pembelajaran sama sekali tidak muncul adanya penggunaan bahasa ibu baik oleh siswa maupun oleh guru. Sekali-sekali guru menggunakan bahasa Indonesia jika siswa tidak dapat memahami konteks dari kosakata yang diajarkan atau pada saat memberikan instruksi. Selain itu, siswa kadangkala menggunakan bahasa Indonesia saat menjawab pertanyaan guru atau mengapresiasi cerita yang dibawakan guru. Gumamangumaman siswa muncul lebih banyak dalam bahasa Indonesia.

Pada saat guru mengecek pemahaman siswa secara lisan, sebagian besar siswa mampu menjawab dalam bahasa Inggris. Selain itu, berdasarkan hasil penilaian evaluasi akhir siswa diketahui bahwa seluruh siswa memahami materi yang disampaikan guru. Siswa dapat menggunakan kemampuan bahasa Inggris yang telah diperolehnya dalam menyebutkan bagian tubuh hewan yang sering ditemui dalam kehidupan sehari-hari. Hal ini sesuai dengan pernyataan dari Fogarty (1991), yaitu pembelajaran terpadu dapat meningkatkan pemahaman siswa tentang kedalaman dan keluasan berbagai materi pelajaran yang diintegrasikan.

Pengajaran Sains menggunakan metode dwibahasa secara terpadu dapat membantu memperdalam pemahamannya terhadap konten materi Sains selain sebagai metode yang membantu siswa dalam pemerolehan bahasa ke tiga atau bahasa Inggris. Pendapat ini sejalan dengan apa yang dikemukakan oleh Haliwell (1992) dalam bukunya yang berjudul Teaching 
English in the Primary Classroom bahwa pengajaran materi subjek dengan media instruksi bahasa Inggris merupakan cara terbaik yang dapat dilakukan untuk menanamkan pemahaman penguasaan bahasa Inggris secara mendalam pada siswa SD. Pembelajaran Sains secara manipulatif dan terpadu dengan bahasa Inggris memiliki kelebihan yaitu dalam peningkatan perbendaharaan kosakata bahasa Inggris siswa (Esler \& Esler: 1996). Pembelajaran manipulatif maksudnya adalah pembelajaran yang menggunakan sumber atau media yang dapat menarik minat siswa untuk belajar mengembangkan kosakata, bukan hanya sebatas membaca istilahistilah dalam buku teks (Sulfemi, \& Kamalia, 2020). Kegiatan pembelajaran yang disajikan oleh guru mengeksplorasi berbagai kosakata baru bahasa Inggris.

Berdasarkan hasil wawancara diketahui bahwa guru menemui kesulitan pada saat membelajarkan Sains dalam bahasa Inggris. Hal ini disebabkan oleh kurangnya keterampilan berbahasa Inggris yang dimiliki guru sehingga rasa kepercayaan dirinya kurang. Akibatnya, guru mengalami kendala dalam mengeksplorasi dan mengembangkan proses pembelajaran menggunakan berbagai istilah bahasa Inggris. Kurangnya keterampilan bahasa Inggris guru menjadi kendala dalam pemerolehan bahasa ke tiga (bahasa Inggris) dalam konteks Sains. Keterampilan bahasa Inggris yang dimaksud adalah dalam hal perbendaharaan kosakata dan pemilihan kata yang sesuai dengan terminologi Sains. Kedua keterampilan ini saling berhubungan karena seringkali beberapa istilah dalam bahasa Inggris memiliki arti yang sama dalam bahasa Indonesia, hanya terminologi dan konteksnya yang berbeda. Kesalahan pemilihan kata menyebabkan konteks yang ingin diajarkan tidak tersampaikan. Pada akhirnya, hal ini menyebabkan kesalahan pemahaman. Kesalahan konsep tersebut biasanya akan terus diingat oleh siswa SD karena kesalahan tersebut berasal dari guru yang dianggap siswa sangat tahu dan memiliki otoritas atas dirinya. kesalahan konsep akan memengaruhi kemampuan siswa dalam mengasimilasi konsep atau pengetahuan baru di masa yang akan datang (Esler \& Esler: 1996).

Pada saat guru melakukan pembelajaran Sains terdapat beberapa kesalahan dalam berbahasa Inggris yang menyebabkan kesalahan konsep IPA. Misalnya, dari dialog yang terjadi antara guru dengan siswa terlihat bahwa guru melakukan kesalahan ketika siswa menyebutkan sirip ikan yang berjumlah empat buah (four). Akan tetapi guru mengatakan bahwa jumlah sirip ikan ada tiga buah (No, there are three fins). Hal ini menimbulkan kesalahan konsep pada diri siswa.

Berdasarkan hasil observasi pembelajaran, terlihat guru berusaha melakukan bimbingan pada siswa untuk memperoleh kosakata bahasa Inggris. Guru tidak mengajarkan istilah bahasa Inggris secara verbal dan menerjemahkannya ke dalam bahasa Indonesia (atau sebaliknya), melainkan melalui action, mimik, media nyata, dan juga bahasa verbal jika siswa menemukan kesulitan menemukan istilah bahasa Inggris yang sesuai dengan konteks dan konten materi pelajaran Sains. Hal senada diungkapkan oleh Esler \& Esler (1996) bahwa saat guru mengajarkan konsep Sains, siswa sering mengalami kebingungan dalam memahami berbagai istilah dan definisi-definisi ilmiah. Esler \& Esler juga menyatakan bahwa untuk meluruskan kesalahan konsepsi siswa terhadap suatu istilah dapat dilakukan dengan mendefinisikan istilah tersebut dalam bahasa yang dimengerti siswa (dalam hal ini bahasa Indonesia karena siswa SD Laboratorium hampir seluruhnya menggunakan bahasa Indonesia dalam kehidupan sehari-hari), menghubungkan konsep dengan konteks dalam kehidupan sehari-hari siswa, dan membantu siswa untuk mengakomodasi pemerolehan bahasa ketiga secara bertahap. 


\section{Upaya Pemertahanan Bahasa Ibu dan Pemerolehan Bbahasa Kedua dan Ketiga dalam Pembelajaran Sains SD}

Habitus linguistik adalah sebuah kecenderungan budaya untuk mengatakan hal-hal tertentu sebagai suatu kompetensi linguistik yang spesifik untuk mengatakan sesuatu 'secara benar' dan kapasitas sosial untuk menggunakan kompetensi itu secara tepat. Habitus ini ditanamkan sejak kecil dengan teguran dan larangan jika kita berkata-kata dengan tidak tepat di dalam situasi tertentu, baik di rumah, maupun di sekolah. Kemampuan untuk berbahasa sesuai kondisi dan kapasitas inilah yang kemudian menjadi kompetensi. Kompetensi ini dibutuhkan di dalam konteks sosial dan pada praktiknya tidak dapat dipisahkan dari penguasaan sebuah bahasa dan juga penguasaan penggunaan bahasa di dalam situasi yang tepat yang dapat diterima secara sosial. Atau dengan kata lain bisa berbahasa sesuai dengan kelas sosial seseorang.

Habitus linguistik di era globalisasi telah dipupuk sejak dini dalam diri siswa SD, baik di lingkungan sekolah maupun keluarga. Penguasaan bahasa Inggris sebagai bahasa ketiga menempati posisi teratas kompetensi yang harus dicapai oleh anak-anak bangsa sebagai implikasi dari peningkatan kualitas pendidikan global.

Pemerintah mungkin kurang peka atau memang sengaja menjadikan bahasa ibu sedikit demi sedikit mulai terpinggirkan, atau memang secara sistemik dibiarkan punah dengan sendirinya, selain itu juga mulai membiarkan bahasa Indonesia (bahasa ke dua) tidak lagi menjadi kebanggan bagi anak-anak sekolah dewasa ini. Gengsi para komponen komunitas pendidikan diasumsikan meningkat jika mereka mampu menguasai bahasa Inggris (bahasa ke tiga). Lalu, dengan alasan apa yang bisa diterima secara logis sehingga mampu menjelaskan, "Mengapa bahasa pengantar pendidikan kita mulai kehilangan entitasnya?" Anak-anak sekarang lebih bangga menggunakan ungkapan-ungkapan dalam interaksi dan komunikasinya menggunakan bahasa Inggris. Apalagi saat ini pihak berkepentingan dalam dunia pendidikan begitu ramainya menggagas dan mengedepankan kelas dwibahasa atau Sekolah Berstandar Internasional baik dari tingkat sekolah dasar yang semakin mengikis identitas lokal siswa sebagai putra-putri daerah maupun sampai sekolah menengah.

Meskipun keluhan tentang penggunaan bahasa Indonesia sebagai bahasa pengantar di SD tidaklah banyak, tetapi kurang lebih 75\% siswa SD di pedesaan bukanlah penutur asli bahasa Indonesia. Oleh karena itu pemakaian bahasa ibu di SD kelas awal masih perlu dilakukan. Selain untuk menjamin kelangsungan pembelajaran juga untuk mencegah gangguan perkembangan kognitif anak. Depdiknas juga harus ekstra memberi pelatihan yang memadai kepada para guru SD serta menyediakan buku teks yang tentu harus berbeda sesuai dengan kebutuhan lingkungan dan budaya setempat dalam mengantarkan anak-anak memahami bahasa Indonesia sebagai bahasa pengantar di sekolah. Sesuai dengan arah otonomi bidang pendidikan, sudah saatnya bagi pemerintah daerah mendesain sendiri buku-buku berbahasa lokal bagi keperluan belajarmengajar anak-anak SD sampai minimum kelas 2, sebelum mulai mengggunakan bahasa Indonesia sebagai bahasa pengantar di sekolah.

Penguasaan sebuah bahasa oleh seorang anak dimulai dengan perolehan bahasa pertama, dalam hal ini bahasa ibu. Ali (1995:77) mengatakan bahasa ibu adalah bahasa pertama yang dikuasai manusia sejak awal hidupnya melalui interaksi dengan sesama anggota masyarakat bahasanya, seperti keluarga dan masyarakat lingkungan. Hal ini menunjukkan bahasa pertama merupakan suatu proses awal dalam mengenal bunyi dan lambang yang disebut bahasa. Pemerolehan bahasa merupakan sebuah proses yang sangat panjang sejak anak belum mengenal sebuah bahasa sampai fasih berbahasa. 
Setelah bahasa ibu diperoleh, pada usia tertentu anak akan mempelajari bahasa kedua sebagai khazanah pengetahuan yang baru. Apabila dalam proses awal menunjukkan pemahaman dan pemerolehan bahasa yang baik dari keluarga dan lingkungan masyarakat, proses pemerolehan bahasa selanjutnya akan mendapatkan kemudahan. Tahapan-tahapan berbahasa ini memberikan pengaruh yang besar dalam proses pemerolehan bahasa anak. Pemerolehan bahasa adalah proses pemahaman dan penghasilan (produksi) bahasa pada diri anak melalui beberapa tahap mulai dari mengeja sampai fasih berbicara (Indrawati dan Oktarina, 2005:21).

Bahasa kedua akan dikuasai secara fasih apabila bahasa pertama yang diperoleh sebelumnya sangat erat hubungannya (khususnya bahasa lisan) dengan bahasa kedua tersebut. Hal itu memerlukan proses dan kesempatan yang banyak. Kefasihan seorang anak untuk menggunakan dua bahasa sangat bergantung pada adanya kesempatan untuk menggunakan kedua bahasa itu. Jika kesempatan banyak, kefasihan berbahasanya semakin baik (Chaer, 1994:66). Bagi siswa yang menggunakan bahasa ibu sebagai bahasa pertama, pemerolehan bahasa ibu pasti mempunyai pengaruh terhadap dirinya dalam proses mendapatkan bahasa kedua yaitu bahasa Indonesia yang baik dan benar, dan bahasa ketiga (bahasa Inggris) di masa depannya.

Orang tua dan lingkungan mempunyai andil besar terhadap pemerolehan bahasa yang akan dipelajari anak di lembaga pendidikan formal. Dalam aliran behavioristik, Tolla (dalam Indrawati dan Oktarina, 2005:24; Sulfemi, \& Yuliani, (2019). menjelaskan bahwa proses penguasaan bahasa pertama dikendalikan dari luar, yaitu oleh rangsangan yang disodorkan melalui lingkungan. Hal ini jelas terlihat dari siswa SD baik di Kecamatan Solokan Jeruk maupun di SD Laboratoeium UPI Kampus Cibiru. Di Kecamatan Solokan Jeruk, keluarga dominan menggunakan bahasa Sunda sebagai bahasa pertama sehingga siswa sangat kental dengan bahasa Sunda dalam aktivitas belajar di sekolah. Pemerolehan bahasa Indonesia sebagai bahasa kedua bagi mereka dirasakan sulit. Hal berbeda di SD Laboratorium bahwa siswa berasal dari keluarga dan lingkungan pergaulan yang menggunakan bahasa Indonesia sebagai bahasa pertama, sehingga dalam proses belajar di sekolah pun mereka lebih banyak menggunakan bahasa Indonesia. Hal ini menunjukkan bahwa bahasa yang digunakan oleh orang tua sebagai orang yang pertama kali dekat dengan diri anak ketika menerima bahasa pertama sangat berdampak terhadap anak dalam tahapan pemerolehan bahasa kedua. Bagi anak, orang tua merupakan tokoh identifikasi. Oleh sebab itu tidaklah mengherankan jika mereka meniru hal-hal yang dilakukan orang tua (Fachrozi dan Diem, 2005:147: Sulfemi, \& Yuliana, 2019).

Apapun bahasa yang diperoleh anak dari orang tua dan lingkungannya akan tersimpan di benaknya sebagai konsep perolehan bahasa anak itu sendiri. Hal ini menunjukkan bahwa keberadaan orang tua dalam berbahasa di dalam keluarga (bahasa ibu) sangat dicermati anak untuk ditirukan. Anak bersifat meniru dari semua konsep yang ada di lingkungannya. Brown (dalam Indrawati dan Oktarina, 2005:24) mengemukakan bahwa posisi ekstrern behavioristik adalah anak lahir ke dunia seperti kertas putih, bersih. Pernyataan itu memberikan penjelasan nyata bahwa lingkungan keluarga terutama orang tua yang memberikan bahasa yang kurang baik (khususnya tuturan lisan) kepada anak akan menjadi dampak negatif yang akan disambut oleh anak sebagai pemerolehan bahasa pertama yang menjadi modal awal bagi seoarang anak untuk menyongsong kehadiran pemerolehan bahasa kedua (Sulfemi, 2018).

Perolehan bahasa kedua (bahasa Indonesia) merupakan sebuah kebutuhan bagi anak ketika sedang mengikuti pendidikan di lembaga formal. Pada lembaga formal guru mempunyai pengaruh yang sangat signifikan terhadap pemerolehan bhasa kedua dan ketiga siswa. Guru akan menjadi figur pengganti orangtua yang memainkan peranan penting dalam memberikan tuturan 
bahasa sebagai contoh bahasa kedua. Penyesuaian antara bahasa ibu dengan bahasa kedua (bahasa Indonesia) yang dituturkan oleh guru memang membutuhkan waktu yang cukup lama. Oleh karena itu, pada kelas rendah (kelas 1-3 SD) penggunaan bahasa ibu sebagai bahasa pengantar dirasakan masih penting (Sulfemi, \& Desmiati, 2018). Pada Kelas 4-6 SD guru harus lebih banyak menggunakan bahasa Indonesia sebagai bahasa pengantar dalam proses pembelajaran. Apabila pada kelas lanjutan guru masih menggunakan bahasa ibu/bahasa daerah sebagai bahasa pengantar pendidikan, dampak negatif yang diperoleh anak akan banyak. Sebaliknya, apabila siswa telah terbiasa mengggunakan bahasa ibu dalam komunikasi di lingkungan formal, guru akan sangat sulit mengenalkan bahasa Indonesia sebagai bahasa kedua. Dampak sistemik akan timbul manakala siswa melanjutkan pendidikannya ke jenjang yang lebih tinggi atau saat siswa dihadapkan pada tuntutan untuk mempelajari bahasa Inggris sebagai bahasa ketiga (Sulfemi, \& Nurhasanah, 2018).

\section{PENUTUP \\ Simpulan dan Saran}

Simpulan penelitian ini adalah (1) kendala yang ditemui dalam pemerolehan bahasa ke dua dan ke tiga (bahasa Indonesia dan bahasa Inggris) pada: a) SD di Kecamatan Solokan Jeruk: pemerolehan bahasa ke dua (bahasa Indonesia) mengalami kendala yaitu latar belakang siswa yang dalam kehidupan sehari-hari di lingkungan keluarga dan pergaulan dengan masyarakat sekitar masih sarat menggunakan bahasa Sunda sebagai bahasa ibu atau bahasa pertama. Pembelajaran menggunakan bahasa Indonesia terhambat. Guru belum mampu melakukan pembelajaran Sains transisi bahasa dari bahasa Sunda ke bahasa Indonesia. Akan tetapi, pembelajaran Sains di SD Laboratorium UPI Kampus Cibiru mengalami kendala dalam pemerolehan bahasa ke tiga yaitu bahasa Inggris akibat dari kurang terampilnya guru berbahasa Inggris. Padahal siswa umumnya memiliki kemampuan bahasa Inggris yang sudah cukup baik. (2) pemunculan bahasa ibu (bahasa Sunda) dalam pembelajaran Sains di SD di Kecamatan Solokan Jeruk sangat mendominasi pembelajaran, siswa lebih banyak menyampaikan jawaban dalam bahasa Sunda, sedangkan di SD Laboratorium UPI Kampus Cibiru, sama sekali tidak muncul bahasa ibu baik dari guru saat membantu siswa memahami istilah Sains dalam bahasa Inggris, dalam instruksi, maupun dari siswa saat pembelajaran berlangsung.

Berdasarkan hasil penelitian, disarankan dalam pembelajaran Sains di lemga formal (SD), guru tidak mengesampingkan pentingnya pemertahanan bahasa ibu. Walaupun pembelajaran Sains dilakukan secara dwibahasa dalam bahasa Indonesia dan bahasa Inggris, alangkah baiknya untuk siswa kelas rendah diberikan exposure bahasa ibu sebagai upaya pelestarian budaya lokal dan identitas masyarakat. Jika siswa sudah mampu menguasai bahasa ibu sebagai bahasa pertama, diharapkan di masa depan ia akan berhasil mengauasai bahasa kedua (bahasa Indonesia) dan bahasa ke tiga (bahasa Inggris). Peran guru SD dan orang tua dalam berbahasa ditunjang oleh faktor pergaulan sehari-hari sangat memberikan dampak yang sangat besar dalam proses pemerolehan bahasa kedua dan ketiga. Pemberian figur berbahasa yang baik oleh orang tua yang diperkuat dengan guru sebagai contoh berbahasa yang baik dan benar di sekolah, akan menjadikan anak mempunyai bekal dalam mempelajari pemerolehan bahasa kedua yaitu bahasa Indonesia dan bahasa ketiga (bahasa Inggris) yang baik dan benar. 


\section{Daftar Rujukan}

Arifin, E. Zaenal dan Farid Hadi. 1991. 1001 Kesalahan Berbahasa. Jakarta:CV Akademika Pressindo.

Arsyad,A., Sulfemi, W.B., \& Fajartriani, T. (2020). Penguatan Motivasi Shalat Dan Karakter Peserta Didik Melalui Pendekatan Pembelajaran Kontekstual Pada Mata Pelajaran Pendidikan Agama Islam. POTENSIA: Jurnal Kependidikan Islam. Vol. 6. No 2. 185204. DOI: http://dx.doi.org/10.24014/potensia.v6i2.9662

Badudu, Jusuf Syarif. 1985. Pelik-pelik Bahasa Indonesia. Bandung: Pustaka Prima.

Boudieu, Piere. 2008. Bahasa dan Kekuasaan Simbolik. Diakses pada Februari 2010. (http:/onisur_wordpress.com/2008/12/04.;)

Chaer, Abdul. 1994. Linguistik Umum. Jakarta: PT Rineka Cipta.

Dedezade, K. 2005. Teaching Bilingual Science (Presented at The Multiverse London Regional Workshop II). London: Not Published

Effendi, Slamet. 1994. Panduan Berbahasa Indonesia dengan Baik dan Benar. Jakarta: PT Dunia Pustaka Jaya

Esler \& Esler. (1996). Teaching Elementary Science. USA: Wadsworth Publishing Company

Fachrozi, Irwan dan Diem, C.D. 2005. "Hubungan Antara Peranan Orangtua, Keterlaksanaan Bahan Bacaan di Perpustakaan Sekolah, dan Minat Baca Siswa SLTP Negeri di Kecamatan Banyuasin III Kabupaten Banyuasin.” Lingua, 6(2): 147.

Fogarty, Robin. (1991). How to Integrate the Curricula. USA: IRI/Skylight Publishing, Inc

Indrawati, Sri dan Santi Oktarina. 2005. "Pemerolehan Bahasa Anak TK: Sebuah Kajian Fungsi Bahasa." Lingua, 7 (1): 21.

Pusat Pembinaan dan Pengembangan Bahasa.1995. Kamus Besar Bahasa Indonesia. Jakarta: Departemen Pendidikan dan Kebudayaan.

Safarina, D. Sopah, dan Indrawati, S. 2006. "Analisis Kesalahan Berbahasa Ragam Tulis Siswa Madrasah Ibtidaiyah Negeri I Palembang." Lingua, 7 (2): 157.

Sulfemi, W. B. (2018). Pengaruh Disiplin Ibadah Sholat, Lingkungan Sekolah, dan Intelegensi Terhadap Hasil Belajar Peserta Didik Mata Pelajaran Pendidikan Agama Islam. Edukasi: Jurnal Penelitian Pendidikan Agama dan Keagamaan. 16 (2), 166-178. DOI : 10.32729/edukasi.v16i2.474.

Sulfemi, W. B., \& Desmiati, Z. (2018). Model Pembelajaran Missouri Mathematics Project Berbantu Media Relief Experience dalam Meningkatkan Hasil Belajar Siswa. Pendas Mahakam: Jurnal Pendidikan Dasar, 3(3), 232-245. Retrieved from https://jurnal.fkipuwgm.ac.id/index.php/pendasmahakam/article/view/269

Sulfemi, W. B., \& Nurhasanah. (2018). Penggunaan Metode Demontrasi dan Media Audio Visual Dalam Meningkatkan Hasil Belajar Peserta Didik Mata Pelajaran IPS. Jurnal Pendas Mahakam. 3 (2). 151-158.. Retrieved from https://jurnal.fkipuwgm.ac.id/index.php/pendasmahakam/article/view/229 
Sulfemi, W. B., \& Minati, H. (2018). Meningkatkan Hasil Belajar Peserta Didik Kelas 3 SD Menggunakan Model Picture And Picture dan Media Gambar Seri. JPsd (Jurnal $\begin{array}{llllll}\text { Pendidikan Sekolah Dasar). } & 4 & \text { (2), } & 228- & 242 .\end{array}$ DOI: http://dx.doi.org/10.30870/jpsd.v4i2.3857

Sulfemi, W. B., \& Setianingsih. (2018), Penggunaan Tames Games Tournament (TGT) Dengan Media Kartu Dalam Meningkatkan Hasil Belajar. Journal of Komodo Science Education $\quad$ (JKSE). $\quad 1 \quad 1$ (1), 14.http://unikastpaulus.ac.id/jurnal/index.php/jkse/article/view/11

Sulfemi, W. B. (2019). Model Pembelajaran Kooperatif Mind Mapping Berbantu Audio Visual Dalam Meningkatkan Minat, Motivasi dan Hasil Belajar IPS. Jurnal PIPSI (Jurnal Pendidikan IPS Indonesia), 4(1), 13-19. DOI: http://dx.doi.org/10.26737/jipips.v4i1.1204

Sulfemi, W. B., \& Yuliani, N. (2019). Model Pembelajaran Contextual Teaching And Learning (CTL) Berbantu Media Miniatur Lingkungan Untuk Meningkatkan Hasil Belajar IPS. Edunomic: Jurnal Ilmiah Pendidikan Ekonomi Fakultas Keguruan Dan Ilmu Pendidikan.7 (2). 73-84. DOI; 10.33603/ejpe.v7i2.1970.

Sulfemi, W. B., \& Yuliana, D (2019). Penerapan Model Pembelajaran Discovery Learning Meningkatkan Motivasi Dan Hasil Belajar Pendidikan Kewarganegaraan. Jurnal Rontal Keilmuan Pancasila dan Kewarganegaraan, 5(1), 17-30. Doi : http://dx.doi.org/10.29100/jr.v5i1.1021

Sulfemi, W. B., \& Mayasari, N. (2019). Peranan Model Pembelajaran Value Clarification Technique Berbantuan Media Audio Visual Untuk Meningkatkan Hasil Belajar $\begin{array}{llll}\text { IPS. Jurnal } & \text { Pendidikan. } & \text { (1). } & \text { 53-68. }\end{array}$ DOI: https://doi.org/10.33830/jp.v20i1.235.2019

Sulfemi, W.B., Siswanto, S., Heryadi, T., \& Soleh, A. N. (2020). Model Project Based Learning Berbantu Media Kartu Dalam Pembelajaran Bahasa Indonesia Materi Kalimat Efektif Pada Surat Undangan. Metalingua: Jurnal Penelitian Bahasa.Vol 18. No 2. 271—284. 238- 253. DOI: http://dx.doi.org/10.26499/metalingua.v18i2.612

Sulfemi, W. B., \& Yasita, O. (2020). Dukungan Sosial Teman Sebaya Terhadap Perilaku Bullying. Jurnal Pendidikan, 21(2), 133-147. https://doi.org/10.33830/jp.v21i2.951.2020.

Sulfemi, W. B. (2020). Pengaruh Rasa Percaya Diri dan Gaya Kepemimpinan Kepala Sekolah Terhadap Kinerja Guru. Nidhomul Haq : Jurnal Manajemen Pendidikan Islam, 5(2), 157-179. https://doi.org/10.31538/ndh.v5i2.557

Sulfemi, W. B., \& Kamalia, Y. (2020). Jigsaw Cooperative Learning Model Using Audiovisual Media To Improve Learning Outcomes. JPsd (Jurnal Pendidikan Sekolah Dasar). 6 (1), 30-42.

Heryadi, Toni., Sulfemi, Wahyu Bagja., \& Retnowati, Sri. (2020). Pengembangan Metode Modeling The Way Berbantu Media Papan Tempel Dalam Pembelajaran Bahasa Indonesia. Jurnal Lingko. Vol 2, No 2. DOI: https://doi.org/10.26499/jl.v2i2.63 